\title{
Pengaruh Variasi Metode Ekstraksi Terhadap Perolehan Senyawa Antioksidan Pada Daun Katuk (Sauropus androgynus (L.) Merr)
}

\author{
Ni Putu Ermi Hikmawanti ${ }^{1}$, Sofia Fatmawati, Zainal Arifin' ${ }^{1}$, dan Vindianita ${ }^{1}$ \\ ${ }^{I}$ Program Studi Farmasi, Fakultas Farmasi dan Sains, Universitas Muhammadiyah Prof. DR. \\ HAMKA, Jalan Delima II/IV Jakarta Timur, Indonesia 13460. \\ E-mail:ermy0907@uhamka.ac.id \\ Riwayat artikel: Dikirim: 25/11/2020; Diterima: 30/12/2020, Diterbitkan: 1/07/2021
}

\begin{abstract}
S. androgynus (Phyllanthaceae) contains natural antioxidant compounds such as phenolics and flavonoid derivatives. The successful to obtain the plant metabolite compounds depends on the extraction method. This study aims to determine the total phenolics and flavonoids content of the ethanolic extract of S. androgynus leaves obtained from three types of extraction methods, namely maceration, Soxhletation, and ultrasonic. Determination of total phenolics and flavonoids content was carried out by colorimetric method using Folin-ciocalteu and $\mathrm{AlCl}_{3} 10 \%$ reagents, respectively. The absorbance of the reaction was measured using a UV-Vis spectrophotometer. Total phenolics content is expressed as equivalent to gallic acid, while total flavonoid content is expressed as equivalent to quercetin. Determination of the extract's antioxidant activity was carried out against DPPH free radical and expressed by the $\mathrm{IC}_{50}(\mathrm{ppm})$ value. The results showed that the ultrasonic extraction method produced the best levels of phenolics (42.96 $\pm 0.51 \mathrm{mgGAE} / \mathrm{g})$, flavonoids (12.05 $\pm 0.36 \mathrm{mgQE} / \mathrm{g})$ and antioxidant activity $\left(\mathrm{IC}_{50}=81.43 \pm 2.63 \mathrm{ppm}\right)$ in ethanolic extract of $\mathrm{S}$. androgynus leaves compared to another extraction method (maceration > Soxhletation). Thus, it can be concluded that the ultrasonic extraction method is an efficient and effective extraction method to produce high antioxidant compounds in ethanolic extract of $S$. androgynus leaves.
\end{abstract}

Keywords: Antioxidant, Extraction, Flavonoids, Phenolics, S. androgynus, Ultrasonic

\begin{abstract}
ABSTRAK
S. androgynus (Phyllanthaceae) mengandung senyawa antioksidan alami seperti fenolik dan turunannya flavonoid. Keberhasilan memperoleh senyawa metabolit tanaman bergantung pada metode ekstraksi. Penelitian ini bertujuan menentukan kadar fenolik dan flavonoid dari ekstrak etanolik daun katuk yang diperoleh dari tiga jenis metode ekstraksi yaitu maserasi, Soxhletasi, dan ultrasonik. Penentuan kadar senyawa fenolik dan flavonoid dilakukan dengan metode kolorimetri masing-masing secara berurutan menggunakan reagen Folin-ciocalteu dan $\mathrm{AlCl}_{3}{ }_{10}$ 10\% . Absorbansi hasil reaksi diukur menggunakan spektrofotometer UV-Vis. Kadar fenolik total dinyatakan sebagai kesetaraannya dengan asam galat, sedangkan kadar flavonoid dinyatakan sebagai kesetaraanya dengan kuersetin. Penentuan aktivitas antioksidan ekstrak dilakukan terhadap radikal DPPH dan dinyatakan dengan nilai $\mathrm{IC}_{50}(\mathrm{ppm})$. Hasil menunjukan bahwa metode ekstraksi ultrasonik menghasilkan kadar fenolik $(42,96 \pm 0,51 \mathrm{mgGAE} / \mathrm{g})$, flavonoid $(12,05 \pm 0,36 \mathrm{mgQE} / \mathrm{g})$ total dan aktivitas antioksidan $\left(\mathrm{IC}_{50}=81,43 \pm 2,63 \mathrm{ppm}\right.$ ) paling baik pada ekstrak etanolik daun $S$. androgynus dibanding dengan metode ekstraksi lain (maserasi > Soxhletasi). Dengan demikian, dapat disimpulkan bahwa metode ekstraksi ultrasonik merupakan metode ekstraksi yang efisien dan efektif untuk menghasilkan senyawa antioksidan yang tinggi pada ekstrak etanolik daun S. androgynus.
\end{abstract}

Kata kunci: Antioksidan, Ekstraksi, Fenolik, Flavonoid, S. androgynus, Ultrasonik 


\section{Hikmawanti, dkk}

DOI : https://doi.org/10.24843/JFU.2021.v10.i01.p01

pISSN: 2301-7716; eISSN: 2622-4607

Jurnal Farmasi Udayana, Vol 10, No 1, Tahun 2021, 01-12

\section{PENDAHULUAN}

Antioksidan merupakan bahan yang digunakan dalam konsentrasi kecil untuk menghambat dan/atau mengurangi oksidasi yang disebabkan oleh suatu oksidan. Salah satunya dengan cara bereaksi dengan radikal melalui donor elektron ataupun hidrogen dan mengubahnya menjadi suatu produk yang lebih stabil (Moharram \& Youssef, 2014). Tanaman merupakan salah satu sumber bahan alam dengan potensi antioksidan alami seperti senyawa fenolik seperti asam fenolat (asam ferulat, asam galat, asam elagat), flavonoid (kuersetin, katekin, hesperidin), tanin, antosianin, liginin; karotenoid (beta-karoten, likopen, lutein); vitamin (vitamin A, C, E) dan sebagainya (Moharram \& Youssef, 2014; Altemimi et al., 2017). Sumber antioksidan dapat diperoleh dari sayuran hijau, salah satunya Sauropus androgynus (L.) Merr. Tanaman ini, di Indonesia, dikenal dengan istilah katuk. Secara empiris, S. androgynus telah lama digunakan untuk antipiretik, pelancar air susu ibu (ASI), dan lain sebagainya (Petrus, 2013). Kapasitas antioksidan daun $S$. androgynus yang berkaitan dengan beragam aktivitas farmakologinya juga telah dilaporkan seperti antimikroba, sitotoksik terhadap sel kanker, antiinflamasi dan penyembuhan luka (Petrus, 2013; Khoo et al., 2015). S. androgynus juga dilaporkan memiliki aktivitas antiobesitas (Patonah et al., 2017), afrodisiaka (Andini, 2014; Rusdi et al., 2018) dan peningkat fertilitas pada tikus jantan (Hikmawanti et al., 2020). Aktivitas farmakologi S. androgynus tidak lepas dari metabolit sekunder yang terkandung didalamnya. Daun S. androgynus dilaporkan mengandung senyawa bioaktif seperti fenolik, tanin, flavonoid, antosianin, fitosterol, dan lain sebagainya (Petrus, 2013). Wijono (2004) melaporkan bahwa senyawa fenolik yang terdeteksi pada daun $S$. androgynus yaitu asam fenolat, asam para hidroksi benzoat, asam ferulat, asam kafeat dan asam vanilat. (Djamil \& Zaidan, 2016) melaporkan bahwa ekstrak metanol daun $S$. androgynus mengandung senyawa flavonoid dalam bentuk flavonol dan flavon. $S$. androgynus termasuk dalam kelompok sayuran dari Indonesia yang teridentifikasi sebagai sumber makanan yang berpotensi kaya akan flavonoid dan antioksidan (Andarwulan et al., 2010).

Ekstraksi adalah langkah awal yang menuntun pada proses isolasi metabolit sekunder tanaman setelah proses preparasi sampel (Khoddami et al. 2013; Stalikas, 2007). Pada proses ekstraksi dengan pelarut, ada dua hal yang penting yaitu waktu dan suhu. Idealnya, peningkatan waktu dan suhu meningkatkan kelarutan senyawa aktif dalam pelarutnya. Ada beberapa jenis ekstraksi metabolit tanaman. Ekstraksi dapat terbagi menjadi ekstraksi dingin (maserasi, perkolasi) dan ekstraksi panas (soxhletasi, refluks). Berdasarkan perkembangannya, ekstraksi terbagi menjadi ekstraksi konvensional (seperti maserasi, perkolasi, sokletasi) dan non konvensional (seperti ekstraksi yang dibantu ultrasonik, microwave dan lain sebagainya). Berdasarkan prosesnya, ekstraksi terbagi atas ekstraksi bertahap (seperti maserasi) dan ekstraksi berkesinambungan (seperti sokletasi dan refluks). Sampai dengan saat ini metode maserasi dan sokletasi merupakan metode klasik yang masih bertahan digunakan dalam produksi ekstrak yang mengandung senyawa bioaktif dari sampel bahan alam terutama tumbuhan obat (Azmir et al., 2013) meskipun telah hadir metode non konvensional yang mungkin menjanjikan proses yang lebih efisien dengan hasil yang efektif (Khoddami et al., 2013). Masing-masing metode ekstraksi memiliki keunggulan dan kekurangan. Kekurangan metode maserasi adalah waktu dan penggunaan pelarut yang lebih banyak dibanding metode Soxhletasi dan metode 
DOI : https://doi.org/10.24843/JFU.2021.v10.i01.p01

pISSN: 2301-7716; eISSN: 2622-4607

Jurnal Farmasi Udayana, Vol 10, No 1, Tahun 2021, 01-12

ekstraksi yang dibantu ultrasonik. Selain itu, metode maserasi juga dianggap kurang efektif karena memiliki efisiensi yang rendah dalam ekstraksi fenolik dibanding metode konvensiaonal lain (Khoddami et al., 2013). Meski demikian, ekstraksi dengan maserasi masih banyak digunakan karena relatif lebih aman untuk senyawa kimia yang bersifat termolabil dimana proses ekstraksi tidak menggunakan panas, dengan proses dan alat yang sederhana serta biaya yang relatif lebih murah (Azwanida, 2015). Sedangkan metode Soxhletasi cukup menggunakan pelarut organik dalam jumlah yang lebih sedikit jika dibanding dengan maserasi. Namun, metode soxhletasi memerlukan pelarut dengan tingkat kemurnian yang lebih tinggi sehingga relatif lebih banyak menghabiskan biaya. Selain itu, metode soxhletasi juga menggunakan panas yang mana tidak cocok untuk senyawa yang termolabil karena dapat menyebabkan degradasi senyawa (Pandey \& Tripathi, 2014). Soxhletasi juga terbatas untuk simplisia kering dan halus dalam jumlah terbatas (Arceusz et al., 2013; Azwanida, 2015; Watson, 2019). Penggunaan metode ekstraksi dengan bantuan ultrasonik dirasa suatu alternatif untuk memberikan solusi dari kekurangan metode maserasi maupun sokletasi untuk menarik senyawa fenolik dan flavonoid (Khoddami et al., 2013).

Proses produksi ekstrak sebagai bahan baku dengan mutu yang baik perlu mempertimbangkan pemilihan metode ekstraksi yang tepat. Melalui penelitian ini dapat diketahui metode ekstraksi yang paling efisien dan efektif dalam menarik senyawa antioksidan berupa fenolik dan flavonoid dari daun $S$. androgynus.

\section{BAHAN DAN METODE}

\section{Bahan dan Alat}

Daun S. androgynus segar diperoleh dari dan dideterminasi di Unit Konservasi Budidaya Biofarmaka (UKBB), Pusat Studi Biofarmaka Tropika LPPM IPB, Bogor, Jawa Barat,
Indonesia. Etanol (Merck, Darmstadt, Jerman) sebagai pelarut pengekstraksi. Asam galat dan kuersetin sebagai standar, serta DPPH $(2,2-$ diphenyl-1-picryl-hydrazyl) (Sigma-Aldrich Co., St. Louis, USA).

Alat-alat penting yang digunakan meliputi: seperangkat alat maserasi, seperangkat alat Soxhletasi, seperangkat alat Ultrasonik Cleaner model 14H (Dentsply Neytech, Burlington, USA), Vacuum Rotary Evaporator seri N-1200 BS (EYELA, Shanghai, Cina), Moisture Analyzer (Mettler Toledo, Switzerland) dan Spektrofotometer UV-Vis Seri UV-1601 (Shimadzu, Kyoto, Jepang).

\section{Metode}

\section{Pembuatan simplisia daun S. androgynus}

Daun S. androgynus segar disortasi basah dan kemudian dicuci sampai bersih. Daun yang telah ditiriskan kemudian dikering-anginkan terlindung dari cahaya matahari langsung pada suhu ruang selama \pm 3-5 hari. Daun yang telah kering kemudian ditumbuk menggunakan mortar. Simplisia kemudian disimpan dalam wadah kering tertutup baik.

\section{Ekstraksi dengan Metode Maserasi}

Ekstraksi daun S. androgynus kering (150,0 g) dilakukan dengan metode maserasi pada suhu ruang menggunakan pelarut etanol $70 \%$ mengikuti prosedur pada Farmakope Herbal Indonesia (Kementerian Kesehatan RI, 2008). Proses ekstraksi dilakukan selama 24 jam sambil sesekali diaduk. Filtrat dipisahkan dari residunya dengan menggunakan kertas saring Whatmann. Residunya diremaserasi kembali sebanyak 3 kali pengulangan dengan pelarut yang baru. Filtrat dikumpulkan dan dievaporasi menggunakan vacuum rotary evaporator pada $50{ }^{\circ} \mathrm{C}$ dan dilanjutkan menggunakan waterbath pada $50{ }^{\circ} \mathrm{C}$ hingga diperoleh ekstrak kental (Kementerian Kesehatan RI, 2008).

\section{Ekstraksi dengan Metode Soxhletasi}


DOI : https://doi.org/10.24843/JFU.2021.v10.i01.p01

pISSN: 2301-7716; eISSN: 2622-4607

Jurnal Farmasi Udayana, Vol 10, No 1, Tahun 2021, 01-12

Daun S. androgynus kering $(150,0 \quad \mathrm{~g})$ diekstraksi dengan menggunakan seperangkat alat Soxhletasi yang telah dirangkai sebelumnya mengikuti prosedur pada Farmakope Herbal Indonesia. Serbuk daun dibungkus dengan kertas saring dan ditempatkan dalam Thimble. Pelarut etanol $70 \%$ dimasukan ke dalam labu alas bulat yang didalamnya telah diisi dengan batu didih. Ekstraksi berlangsung selama 8 jam. Ekstrak etanol yang diperoleh diuapkan pelarutnya dengan menggunakan vacuum rotary evaporator pada $50{ }^{\circ} \mathrm{C}$ dan dilanjutkan dengan menggunakan waterbath pada $50{ }^{\circ} \mathrm{C}$ hingga diperoleh ekstrak kental (Kementerian Kesehatan RI, 2008).

\section{Ekstraksi dengan Metode Ultrasonik}

Daun S. androgynus (150,0 g) dalam gelas kimia diekstraksi dengan pelarut etanol $70 \%$ (1:10) b/v. Campuran tersebut dimasukan ke dalam alat ultrasonik dengan frekuensi $50 \mathrm{~Hz}$ suhu $40{ }^{\circ} \mathrm{C}$ selama 45 menit. Filtrat disaring dengan kertas saring terhadap residunya, kemudian diuapkan dengan menggunakan vacuum rotary evaporator pada $50{ }^{\circ} \mathrm{C}$ dan dilanjutkan dengan menggunakan waterbath pada $50{ }^{\circ} \mathrm{C}$ hingga diperoleh ekstrak kental.

\section{Penentuan Sifat Fisiko-Kimia Ekstrak}

Ekstrak etanol $70 \%$ daun S. androgynus ditetapkan parameter fisiko-kimianya meliputi organoleptis, persentase rendemen ekstrak, dan kadar abu total sesuai prosedur yang tertera pada Farmakope Herbal Indonesia (Kementerian Kesehatan RI, 2008). Penentuan kadar air dilakukan menggunakan alat moisture balance analyzer.

\section{Identifikasi Kandungan Kimia secara Kualitatif}

Skrining fitokimia dilakukan secara kualitatif menggunakan pereaksi deteksi berdasarkan prosedur yang tertera pada Hanani (2015) dan Farmakope Herbal Indonesia (Kementerian Kesehatan RI, 2008). Golongan senyawa yang diidentifikasi pada ekstrak etanol $70 \%$ daun $S$. androgynus meliputi fenolik, flavonoid, tanin, saponin, alkaloid, steroid dan triterpenoid. Identifikasi fenolik menggunakan pereaksi $\mathrm{FeCl}_{3} 3 \%$. Identifikasi flavonoid menggunakan serbuk Mg dan asam klorida pekat. Identifikasi tanin menggunakan pereaksi gelatin $10 \%$. Identifikasi saponin dilakukan dengan uji buih. Identifikasi alkaloid menggunakan pereaksi Dragendorff, Mayer dan Bouchardat. Identifikasi steroid/triterpenoid menggunakan pereaksi asam asetat anhidrat dan asam sulfat pekat.

\section{Penentuan Kadar Fenolik Total}

Penentuan kadar senyawa fenolik total mengikuti prosedur Yang et al., (2007) dengan modifikasi menggunakan pereaksi FolinCiocalteu. Pembuatan kurva kalibrasi menggunakan larutan asam galat sebagai standar dengan rentang konsentrasi 18-66 ppm. Hubungan konsentrasi asam galat (x) dengan absorbansinya (y) diplot hingga menghasilkan persamaan garis linear $(y=b x \pm a)$. Masingmasing ekstrak etanol daun S. androgynus 1000 ppm dalam etanol dipipet sebanyak $0,3 \mathrm{~mL}$ lalu ditambahkan 1,5 mL pereaksi Folin-Ciocalteu (yang telah diencerkan 1:10) dan dihomogenkan. Larutan diinkubasikan selama 3 menit, kemudian ditambahkan 1,2 mL larutan $\mathrm{Na}_{2} \mathrm{CO}_{3} \quad 7,5 \%$ dan dicukupkan dengan air sampai diperoleh volume total $10 \mathrm{~mL}$. Campuran diinkubasi kembali selama 60 menit pada suhu kamar. Absorbansi larutan ekstrak diukur menggunakan spektrofotometer UV-Vis dengan panjang gelombang maksimum pada $756,5 \mathrm{~nm}$ di suhu ruang. Absorbansi yang diperoleh diplot ke dalam persamaan garis linear dan kemudian kadar fenolik total dihitung dengan rumus: kadar fenolik dalam larutan $(\mu \mathrm{g} / \mathrm{mL})$ dikali dengan faktor pengenceran dan volume larutan $(\mathrm{mL})$ dan dibagi dengan bobot ekstrak (g). Kadar senyawa fenolik total dinyatakan dalam $\mathrm{mg}$ yang setara dengan asam galat per gram ekstrak. Pengujian tiap ekstrak dilakukan 5 kali 


\section{Hikmawanti, dkk}

DOI : https://doi.org/10.24843/JFU.2021.v10.i01.p01

pISSN: 2301-7716; eISSN: 2622-4607

Jurnal Farmasi Udayana, Vol 10, No 1, Tahun 2021, 01-12

pengulangan dan dilaporkan dalam rata-rata \pm SD.

\section{Penentuan Kadar Flavonoid Total}

Penentuan kadar senyawa flavonoid total mengikuti prosedur pada Chang et al., (2002) dengan modifikasi. Standard yang digunakan adalah kuersetin. Larutan kuersetin dengan rentang konsentrasi 33-129 ppm digunakan untuk membuat kurva kalibrasi. Hubungan konsentrasi kuersetin (x) dengan absorbansinya (y) diplot hingga menghasilkan persamaan garis linear $(\mathrm{y}=\mathrm{bx} \pm \mathrm{a})$. Masing-masing ekstrak etanol daun $S$. androgynus dalam metanol dipipet sebanyak 0,5 mL lalu ditambahkan 1,5 $\mathrm{mL}$ metanol dan ditambahkan pereaksi $0,1 \mathrm{~mL}$ $\mathrm{AlCl}_{3} 10 \%, 0,1 \mathrm{~mL}$ natrium asetat $1 \mathrm{M}$ dan cukupkan dengan aquadest sampai $5 \mathrm{~mL}$. Larutan diinkubasi selama 60 menit pada suhu kamar. Absorbansi larutan ekstrak diukur dengan spektrofotometer UV-Vis pada panjang gelombang $434 \mathrm{~nm}$. Absorbansi yang diperoleh diplot ke dalam persamaan garis linear dan kemudian kadar flavonoid total dihitung dengan rumus: kadar flavonoid dalam larutan $(\mu \mathrm{g} / \mathrm{mL})$ dikali dengan faktor pengenceran dan volume larutan $(\mathrm{mL})$ dan dibagi dengan bobot ekstrak (g). Kadar senyawa flavonoid total dinyatakan dalam $\mathrm{mg}$ yang setara dengan kuersetin per gram ekstrak. Pengujian tiap ekstrak dilakukan 5 kali pengulangan dan dilaporkan dalam rata-rata \pm SD.

\section{Pengujian Aktivitas Antioksidan}

Pengujian aktivitas antioksidan ekstrak etanol $70 \%$ daun $S$. androgynus dilakukan dengan metode DPPH mengikuti prosedur (Wan et al., 2011) dengan modifikasi. Kuersetin digunakan sebagai pembanding. Ekstrak dilarutkan dalam methanol dan diencerkan menjadi 5 variasi konsentrasi, yaitu 20, 40, 60, 80, dan 100 ppm. Larutan kuersetin dilarutkan dalam methanol dan diencerkan menjadi 2, 4, 6, 8, dan $10 \mathrm{ppm}$. Masing-masing variasi konsentrasi dari larutan ekstrak atau kuersetin dipipet $0,2 \mathrm{~mL}$ dan ditambahkan $1 \mathrm{~mL}$ DPPH $0,5 \mathrm{mM}$ dalam metanol. Larutan dicukupkan dengan methanol hingga volume total $5 \mathrm{~mL}$. Campuran dalam tube yang dilapisi dengan kertas aluminium foil, diinkubasi selama 30 menit pada suhu ruang dengan kondisi gelap. Larutan blanko dibuat dari $1 \mathrm{~mL}$ DPPH yang dicampur dengan $4 \mathrm{~mL}$ methanol. Selanjutnya, serapan diukur pada panjang gelombang 515,5 nm. Tiap seri konsentrasi masing-masing sampel diuji triplo. Hasil dilaporkan dalam rata-rata \pm SD. Perhitungan persentase penghambatan radikal DPPH menggunakan rumus:

$$
\text { Inhibition of DPPH }(\%)=\frac{A b-A s}{A b} \times 100
$$

dimana Ab merupakan absorbansi blanko dan As merupakan absorbansi sampel.

\section{Analisis data}

Data dianalisis menggunakan analisis multivariat untuk mengetahui pengaruh metode ekstraksi terhadap perolehan kadar fenolik, flavonoid dan aktivitas antioksidan $(\alpha=0,05)$. Hubungan antara variable kadar fenolik, flavonoid serta antioksidan dianalisis dengan menggunakan uji Korelasi (Pearson test). Pengaruh dari hubungan tersebut selanjutnya dianalisis dengan menggunakan regresi berganda $(\alpha=0,05)$.

\section{HASIL}

Hasil penentuan fisiko-kimia ekstrak etanol $70 \%$ daun S. androgynus dari variasi metode ekstraksi dapat dilihat pada Tabel 1. Berdasarkan hasil pada Tabel 1., persentase rendemen ekstrak terhadap simplisia yang diekstraksi paling tinggi ditemukan pada ekstrak yang dihasilkan dari metode ultrasonik yaitu sebesar 36,29\% (Ultrasonik > Maserasi > Soxhletasi).

Berdasarkan hasil pada Tabel 1., kadar abu yang dihasilkan oleh semua ekstrak adalah sekitar 6,22-6,76\%. Kadar abu ditetapkan untuk memberikan gambaran kandungan mineral yang berasal dari tanaman ataupun dari luar 
DOI : https://doi.org/10.24843/JFU.2021.v10.i01.p01

pISSN: 2301-7716; eISSN: 2622-4607

Jurnal Farmasi Udayana, Vol 10, No 1, Tahun 2021, 01-12

tanaman (Departemen Kesehatan RI, 2000). Nilai kadar air masing-masing ekstrak diperoleh sebesar 2,08-2,89\%. Persentase kadar air ditetapkan untuk memberikan gambaran batas maksimal banyaknya air yang terkandung dalam ekstrak terutama untuk bahan yang menyerap kelembaban dengan cepat. Keberadaan air dalam bahan yang tinggi menjadikannya tempat tumbuh yang baik untuk mikroba (World Health Organization, 1998).
Penentuan menggunakan moisture analyzer merupakan cara yang efisien untuk pengukuran dengan jumlah sampel yang cukup banyak dalam waktu analisis yang singkat.

Hasil identifikasi kandungan kimia ekstrak etanol $70 \%$ daun S. androgynus pada Tabel 2., menunjukan keberadaan senyawa alkaloid, fenolik, flavonoid, tanin, saponin, dan steroid.

Tabel 1. Karakteristik fisiko-kimia ekstrak etanol $70 \%$ daun $S$. androgynus dari tiga metode ekstraksi yang berbeda

\begin{tabular}{llll}
\hline \multirow{2}{*}{ Karakteristik Fisiko-Kimia } & \multicolumn{3}{c}{ Metode Ekstraksi } \\
\cline { 2 - 4 } Organoleptis & \multicolumn{1}{c}{ Maserasi } & \multicolumn{1}{c}{ Soxhletasi } & Ultrasonik \\
- Warna & Coklat kehitaman & Coklat kehitaman & Hijau kecoklatan \\
- Bentuk & Ekstrak kental & Ekstrak kental & Ekstrak kental \\
- Bau & Khas & Khas & Khas \\
- Rasa & Agak pahit & Agak pahit & Agak pahit \\
Rendemen Ekstrak $(\%, b / b) \pm$ SD & $35,34 \pm 3,09$ & $24,96 \pm 1,34$ & $36,29 \pm 3,56$ \\
Kadar Abu Total $(\%, b / b) \pm$ SD & $6,76 \pm 0,79$ & $6,52 \pm 0,83$ & $6,22 \pm 1,85$ \\
Kadar Air $(\%, b / b) \pm$ SD & $2,08 \pm 0,65$ & $2,89 \pm 0,56$ & $4,42 \pm 0,88$ \\
\hline
\end{tabular}

Tabel 2. Hasil identifikasi kandungan kimia ekstrak etanol $70 \%$ daun S. androgynus yang diekstraksi dengan tiga metode ekstraksi yang berbeda

\begin{tabular}{cccccccc}
\hline \multirow{2}{*}{ Metode Ekstraksi } & \multicolumn{7}{c}{ Senyawa Kimia yang Diidentifikasi } \\
\cline { 2 - 7 } & Alkaloid & Flavonoid & Fenolik & Saponin & Tanin & Terpenoid & Steroid \\
\hline Maserasi & + & + & + & + & + & - & + \\
Soxhletasi & + & + & + & + & + & - & + \\
Ultrasonik & + & + & + & + & + & - & + \\
\hline
\end{tabular}

Rentang konsentrasi asam galat yang digunakan pada penentuan kurva baku asam galat adalah 18-66 ppm. Kurva Kalibrasi Asam Galat menghasilkan persamaan garis linear $\mathrm{y}=0,0093 \mathrm{x}+0,1824$ dengan nilai $\mathrm{r}=$ 0,99 . Sedangkan, rentang konsentrasi penentuan kurva baku kuersetin adalah 33129 ppm. Kurva Kalibrasi Asam Galat menghasilkan persamaan garis linear $\mathrm{y}=$ $0,0042 x+0,1897$ dengan nilai $r=0,99$. Nilai r mendekati angka 1 menunjukan bahwa persamaan garis tersebut linear. Hasil penentuan kadar fenolik total dan flavonoid total dari masing-masing ekstrak daun $S$. androgynus yang diekstraksi dengan tiga jenis metode ekstraksi dapat dilihat pada Gambar 1. dan Gambar 2. Berdasarkan hasil tersebut dapat terlihat bahwa, metode ekstraksi yang dibantu dengan ultrasonik memberikan hasil perolehan senyawa 
fenolik dan flavonoid yang lebih tinggi dibandingkan metode lainnya (Ultrasonik>Maserasi $>$ Soxhletasi).

Grafik pada Gambar 3. menunjukan potensi antioksidan dari ekstrak etanol $70 \%$ daun $S$. androgynus yang diekstrak dengan metode ultrasonik $($ IC50 $=81,43 \mathrm{ppm}$ ) terhadap radikal DPPH dibandingkan metode lainnya (Ultrasonik > Maserasi > Soxhletasi). Berdasarkan hasil uji multivariat, diperoleh bahwa ketiga metode ekstraksi punya pengaruh yang signifikan terhadap kadar fenolik, flavonoid dan aktivitas antioksidan (nilai $\mathrm{IC}_{50}$ ) dengan nilai signifikansi 0,000 (>0,05). Pada uji Pearson Correlation menunjukan bahwa hasil penafsiran korelasi diperoleh hasil bahwa antara fenolik dan flavonoid memiliki hubungan (korelasi) positif yang kuat dengan nilai $+0,682(>0,5)$ yang artinya, semakin tinggi kadar fenolik ada kecenderungan semakin tinggi pula kadar flavonoid, dan sebaliknya. Sedangkan antara fenolik dan flavonoid terhadap aktivitas antioksidan (nilai $\mathrm{IC}_{50}$ ) memiliki korelasi yang lemah (masing-masing secara berturutturut $-0,923$ dan -0,911). Nilai signifikansi hasil korelasi fenolik, flavonoid dan nilai $\mathrm{IC}_{50}$ menunjukan bahwa ketiganya berkorelasi secara nyata (sig. 0,000<0,05). Hasil uji regresi berganda menunjukan bahwa hubungan antara $\mathrm{IC}_{50}$ dengan fenolik dan flavonoid adalah kuat $(\mathrm{R}=0,931>0,5)$. Hasil uji $F$ diperoleh nilai $F=29,195$ dengan nilai signifikasi $0,000<0,05$ yang berarti bahwa kadar fenolik dan flavonoid secara bersama-sama berpengaruh terhadap aktivitas antioksidan (nilai $\mathrm{IC}_{50}$ ).

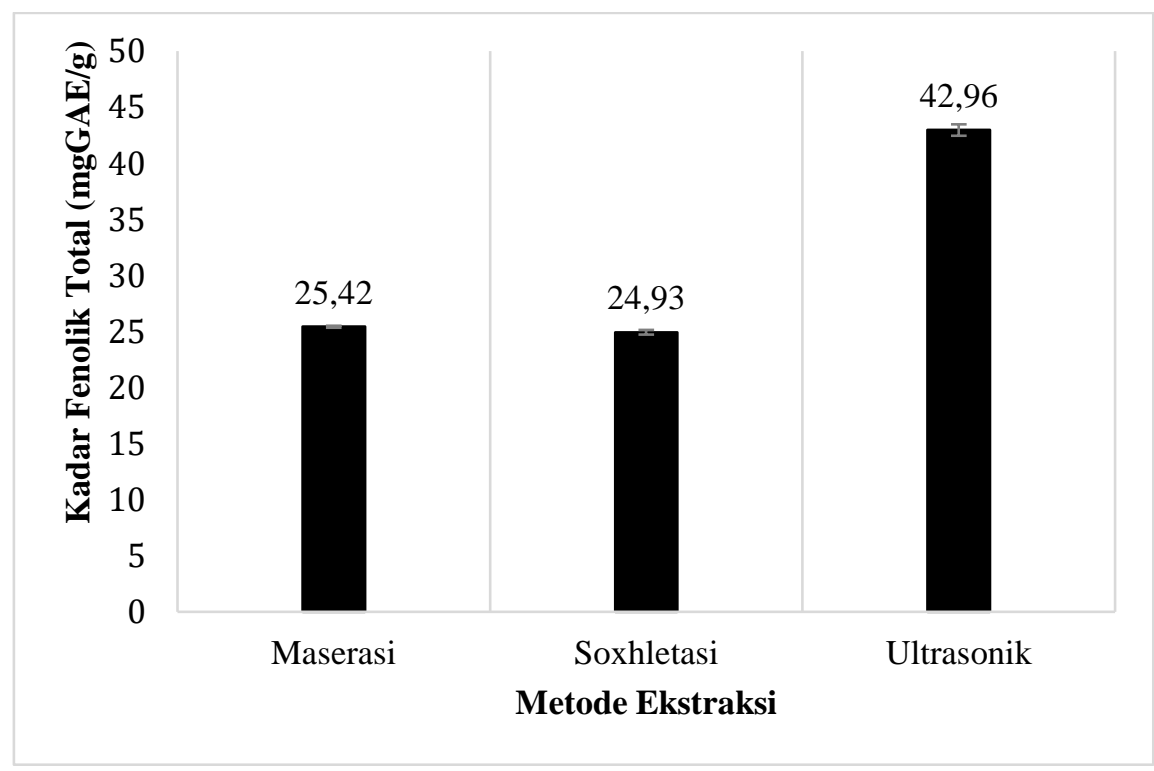

Gambar 1. Grafik perbedaan kadar fenolik total ekstrak etanol $70 \%$ daun S. androgynus yang diekstraksi dengan metode ekstraksi berbeda. Pengujian tiap ekstrak dilakukan 5 kali pengulangan dan dilaporkan dalam rata-rata \pm SD 
Hikmawanti, dkk

DOI : https://doi.org/10.24843/JFU.2021.v10.i01.p01

pISSN: 2301-7716; eISSN: 2622-4607

Jurnal Farmasi Udayana, Vol 10, No 1, Tahun 2021, 01-12

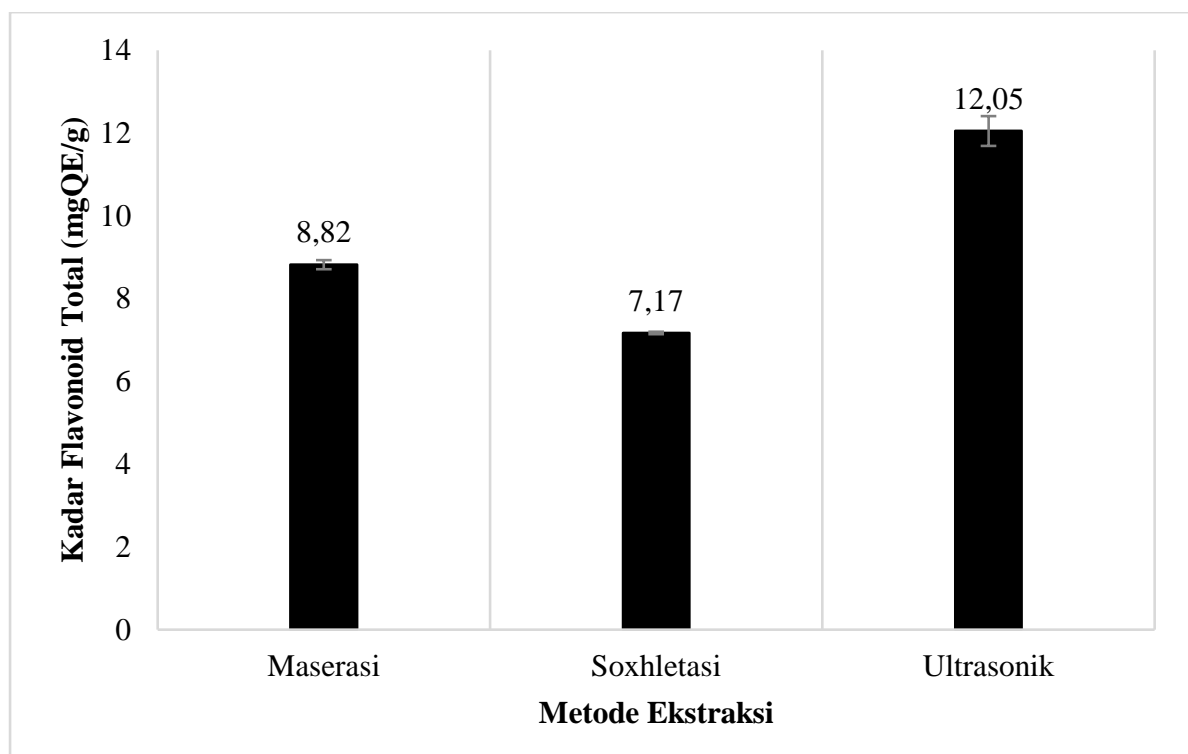

Gambar 2. Grafik perbedaan kadar flavonoid total ekstrak etanol 70\% daun S. androgynus yang diekstraksi dengan metode ekstraksi berbeda. Pengujian tiap ekstrak dilakukan 5 kali pengulangan dan dilaporkan dalam rata-rata \pm SD

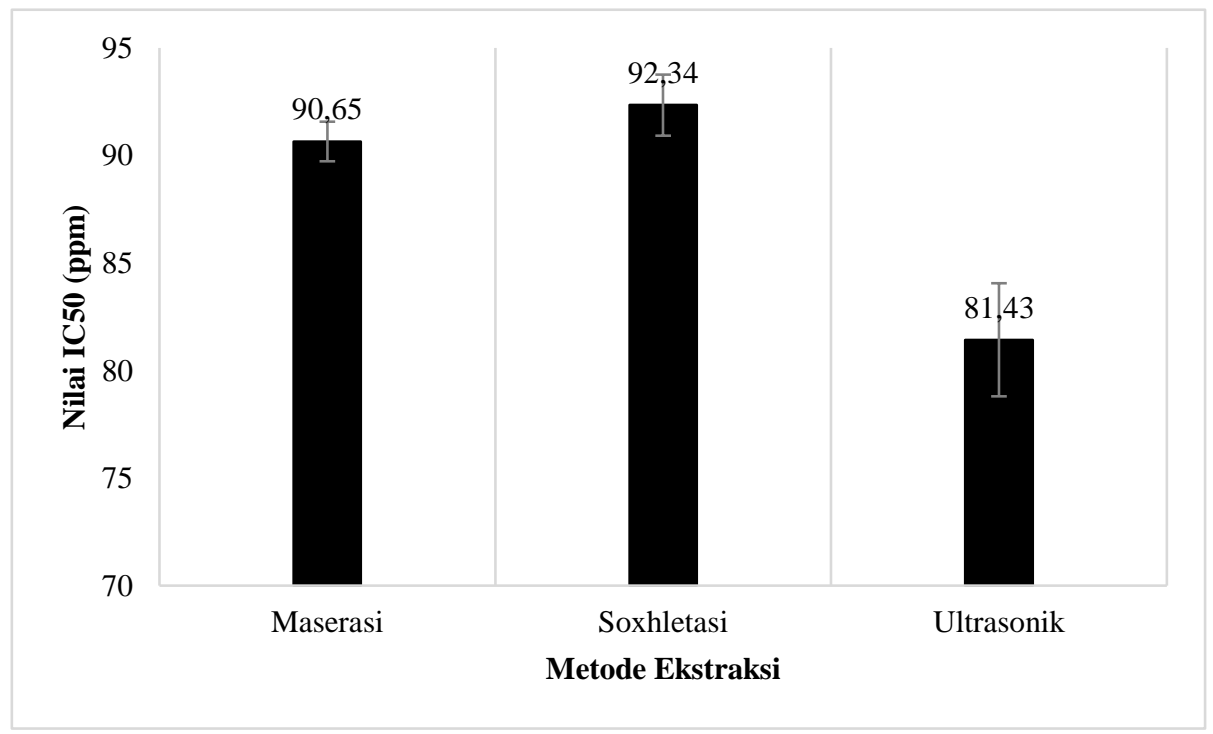

Gambar 3. Grafik perbedaan nilai $\mathrm{IC}_{50}$ ekstrak etanol $70 \%$ daun S. androgynus yang diekstraksi dengan metode ekstraksi berbeda. Pengujian tiap ekstrak dilakukan 5 kali pengulangan dan dilaporkan dalam rata-rata \pm SD 
DOI : https://doi.org/10.24843/JFU.2021.v10.i01.p01

pISSN: 2301-7716; eISSN: 2622-4607

Jurnal Farmasi Udayana, Vol 10, No 1, Tahun 2021, 01-12

\section{PEMBAHASAN}

Ekstraksi yang dibantu dengan ultrasonik dilakukan dengan frekuensi radiasi ultrasonik $>20 \mathrm{kHz}$. Sonikasi menghasilkan gelombanng suara yang menyebabkan gelembung kavitasi pada jaringan bahan. Hal ini mengakibatkan terjadinya kerusakan pada dinding sel yang kemudian menyebabkan isi sel berupa metabolit tanaman keluar (Khoddami et al., 2013). Hal ini yang menyebabkan metode tersebut mampu menghasilkan metabolit aktif yang lebih banyak terekstraksi. Etanol sebagai pelarut pengekstraksi memiliki kemampuan mengekstraksi polifenol, tannin, poliasetilena, flavonol, terpenoid, sterol dan alkaloid (Azmir et al., 2013; Pandey \& Tripathi, 2014). Pelarut pengekstraksi yang umumnya digunakan untuk ekstraksi polifenol dan fenolik sederhana adalah alkohol (methanol, etanol dan propanol), air, aseton dan etil asetat (Stalikas, 2007). Sedangkan flavonoid umumnya diekstraksi dengan metanol, etanol, aseton air atau campuran pelarut tersebut menggunakan ekstraksi panas seperti refluks atau Soxhletasi. Perbedaan hasil yang diperoleh dalam tiap pelarut tersebut tergantung dari jenis dan sifat dari senyawa fenolik pada tanaman (Khoddami et al., 2013).

Penentuan kadar fenolik dan flavonoid daun $S$. androgynus dilakukan dengan metode kolorimetri menggunakan spektrofotometer UV-Vis. Fenolik merupakan suatu senyawa dengan jumlah terbesar di alam yang sering ditemukan di tumbuhan. Penentuan kadar fenolik dari sampel bahan alam dapat dilakukan dengan berbagai metode seperti FolinDenis, Folin-ciocalteu, titrasi permanganat, kolorimetri dengan garam besi dan serapan UV. Namun, metode Folin-ciocalteu merupakan metode yang paling sering dipilih dibanding metode lainnya karena dianggap sebagai metode yang sederhana dan reproduksibel serta dapat digunakan secara luas untuk menentukan senyawa fenolik secara kuantitatif dari bahan dan ekstrak tanaman. Metode ini bergantung pada transfer elektron dari medium alkali dari senyawa fenolik fosfomolibdat/fosfotungstat membentuk kompleks biru $\left.\left(\mathrm{PMoW}_{11} \mathrm{O}_{4} 0\right)^{4-}\right)$ yang ditentukan secara spektroskopi sekitar $760 \mathrm{~nm}$. Asam galat digunakan sebagai standard. Kadar fenolik total kemudian disetarakan dengan mg dari asam galat tiap gram atau kilogram atau liter dari ekstrak (Dai \& Mumper, 2010).

Flavonoid merupakan suatu turunan fenolik dengan sistem cincin aromatis terkonjugasi sehingga mampu memberikan serapan pada sinar UV. Kuersetin digunakan sebagai standard dan merupakan salah satu kelompok flavonol dengan gugus hidroksil yang tersubstitusi pada karbon nomor 5 dan 7 pada cincin aromatis A serta karbon nomor 3 pada $\mathrm{C}$ heterosiklik, dan gugus keto yang tersubstitusi pada karbon nomor 4 pada cincin $\mathrm{C}$ heterosiklik. Hidroksil pada karbon nomor 3 atau 5 serta keto pada posisi karbon nomor 4 inilah yang dengan $\mathrm{AlCl}_{3}$ akan membentuk kompleks kuning cerah yang stabil pada sinar tampak/visible) (Hanani, 2015).

Semua teknik ekstraksi memiliki kesamaan tujuan, yaitu untuk mengekstrak senyawa bioaktif yang ditargetkan dari sampel tanaman, untuk meningkatkan selektivitas, meningkatkan kepekaan bioassay dengan meningkatkan konsentrasi senyawa yang ditargetkan, serta untuk menyediakan metode yang ajeg dan dapat direproduksi dari matriks sampel (Azmir et al., 2013). Ekstraksi yang dibantu dengan ultrasonik mampu menghasilkan senyawa fenolik (termasuk flavonoid) yang lebih tinggi karena sampel kontak dengan pelarut secara kontinu 
DOI : https://doi.org/10.24843/JFU.2021.v10.i01.p01

pISSN: 2301-7716; eISSN: 2622-4607

Jurnal Farmasi Udayana, Vol 10, No 1, Tahun 2021, 01-12

dengan prosedur yang cepat, mudah, dan dapat dioperasikan dengan cepat dalam berbagai pelarut untuk sediaan skala besar yang sesuai tujuan industri dibandingkan dengan metode konvensional seperti maserasi (Khoddami et al., 2013).

$\mathrm{DPPH}^{\bullet}$ merupakan suatu radikal bebas. Pengujiannya didasarkan pada pengukuran kapasitas peredaman oleh suatu antioksidan yang diukur pada panjang gelombang sekitar 515-517 nm. Aktivitas antioksidan dihitung dengan menentukan penurunan absorbansi produk pada konsentrasi yang berbeda dan dibandingkan dengan absorbansi blanko (tanpa bahan uji). Metode ini merupakan metode yang sederhana, akurat, valid, sensitif, dan relatif murah serta reproduksibel. Kelemahan dari metode ini yaitu radikal DPPH berinteraksi juga dengan radikal lainnya (alkil), dan sensitif pada beberapa basa Lewis. Selain itu, metode ini juga memerlukan pelarut organik dalam pengujiannya. Keberadaan oksigen dapat bereaksi dengan DPPH secara langsung dengan kondisi tanpa perlindungan cahaya yang kemudian menyebabkan penurunan serapan (Singh \& Singh, 2008).

Fenolik mampu meredam reactive oxygen species (ROS) meliputi spesies oksigen radikal dan non radikal seperti $\mathrm{O}^{-\bullet}, \mathrm{HO}^{\bullet}, \mathrm{NO}^{\bullet}, \mathrm{H}_{2} \mathrm{O}_{2},{ }^{1} \mathrm{O}_{2}, \mathrm{HOCl}$, dan juga radikal bebas $\mathrm{RO}^{\bullet}$ dan $\mathrm{ROO}^{\bullet}$ yang umumnya sebagai pengoksidasi. Ada dua mekanisme antioksidan, yaitu (1) kemampuan gugus fungsi fenol untuk mendonorkan atom Hidrogen ke radikal bebas. Mekanisme ini disebut dengan mekanisme transfer atom hydrogen (hydrogen-atom transfer, HAT); Transfer elektron tunggal (single-electron transfer, SET) dari antioksidan fenolik (AROH) menjadi radikal bebas $\left(\mathrm{R}^{\bullet}\right.$ dengan membentuk kation radikal yang stabil $\left(\mathrm{ArOH}^{\bullet+}\right)$ (Quideau et al., 2011). Flavonoid memiliki beberapa mekanisme kerja sebagai antioksidan, salah satunya dengan peredaman radikal secara langsung. Flavonoid akan dioksidasi oleh radikal, menghasilkan radikal yang lebih stabil (kurang reaktif). Dengan kata lain, flavonoid menstabilkan ROS dengan bereaksi dengan radikal. Hal ini terjadi karena tingginya reaktivitas dari gugus hidroksil dari flavonoid (Nijveldt et al., 2001).

Metode ekstraksi yang dibantu ultrasonik terbukti mampu menghasilkan ekstrak dengan rendemen ekstrak dan kandungan senyawa antioksidan yang tinggi dari daun S. androgynus. Namun, dirasa masih perlu dilakukan optimasi dengan parameter variasi waktu, frekuensi, rasio bahan pelarut, suhu serta variasi pelarut menggunakan ekstraksi ultrasonik untuk menghasilkan senyawa antioksidan berupa fenolik dan flavonoid yang paling baik pada daun $S$. androgynus.

\section{KESIMPULAN}

Berdasarkan penelitian yang telah dilakukan, dapat disimpulkan bahwa metode ekstraksi yang diujikan berpengaruh terhadap perolehan senyawa antioksidan dari daun $S$. androgynus. Metode ekstraksi ultrasonik merupakan metode ekstraksi yang relatif efektif serta efisien dari segi biaya, waktu, penggunaan energi, bahan dan pelarut pengekstraksi dibanding dengan metode konvensional.

\section{UCAPAN TERIMAKASIH}

Ucapan terimakasih tim penulis sampaikan kepada Dr. apt. Hadi Sunaryo, M.Si selaku Dekan Fakultas Farmasi dan Sains, Universitas Muhammadiyah Prof. DR. HAMKA atas izin dan dukungan fasilitas di Laboratorium Terpadu. Ucapan terimakasih juga tim penulis sampaikan kepada Lembaga Penelitian dan Pengembangan Universitas Muhammadiyah Prof. DR. HAMKA 
DOI : https://doi.org/10.24843/JFU.2021.v10.i01.p01

pISSN: 2301-7716; eISSN: 2622-4607

Jurnal Farmasi Udayana, Vol 10, No 1, Tahun 2021, 01-12

selaku pemberi dana Hibah Penelitian Internal Skema Penelitian Dasar Keilmuan Batch II tahun 2019.

\section{DAFTAR PUSTAKA}

Altemimi, A., Lakhssassi, N., Baharlouei, A., \& Watson, D. G. (2017). Phytochemicals: Extraction, Isolation, and Identification of Bioactive Compounds from Plant Extracts. Plants, 6(42), 1-23.

Andarwulan, N., Batari, R., Sandrasari, D. A., Bolling, B., \& Wijaya, H. (2010). Flavonoid content and antioxidant activity of vegetables from Indonesia. Food Chemistry, 121(4), 1231-1235.

Andini, D. (2014). Potential Of Katuk Leaf (Sauropus androgynus L. Merr) As Aphrodisiac. Journal Majority, 3(7), 16-21.

Arceusz, A., Wesolowski, M., \& Konieczynski, P. (2013). Methods for Extraction and Determination of Phenolic Acids in Medicinal Plants : A Review. Natural Product Communications, 8(12), 1821-1829.

Azmir, J., Zaidul, I. S. M., Rahman, M. M., Sharif, K. M., Mohamed, A., Sahena, F., ... Omar, A. K. M. (2013). Techniques for extraction of bioactive compounds from plant materials: A review. Journal of Food Engineering, 117(4), 426-436.

Azwanida, N. N. (2015). Review on the Extraction Methods Use in Medicinal Plants, Principle, Strength and Limitation. Medicinal and Aromatic Plants, 4(3), 1-6.

Chang, C.-C. ., Yang, M.-H. ., Wen, H.-M. ., \& Chern, J.-C. (2002). Estimation of Total Flavonoid Content in Propolis by Two Complementary Colorimetric Methods. Journal of Food and Drug Analysis, 10(3), 178182.

Dai, J., \& Mumper, R. J. (2010). Plant phenolics: Extraction, analysis and their antioxidant and anticancer properties. Molecules, 15(10), 73137352.

Departemen Kesehatan RI. (2000). Parameter Standar Umum Ekstrak Tumbuhan (p. 76). p. 76. Jakarta: Ministry of Health, Indonesia.

Djamil, R. ., \& Zaidan, S. (2016). Isolasi Senyawa Flavonoid dari Ekstrak Metanol Daun Katuk (Sauropus $\begin{array}{lll}\text { androgynus (L.) Merr), } & \end{array}$ Euphorbiaceae. Jurnal Ilmu Kefarmasian Indonesia, 14(1), 5761.

Hanani, E. (2015). Analisis Fitokimia (In Bahasa). Jakarta: Buku Kedokteran EGC.

Hikmawanti, N. P. E., Rusdi, N. K., \& Yulida, S. (2020). Evaluation of sperm quality in male rats treated with Sauropus androgynus (L.) Merr. leaf fractions. Pharmaciana, 10(2), 193-200.

Kementerian Kesehatan RI. (2008). Farmakope Herbal Indonesia (FHI) (Ed. 1). Jakarta: Kementerian Kesehatan RI.

Khoddami, A., Wilkes, M. A., \& Roberts, T. H. (2013). Techniques for analysis of plant phenolic compounds. Molecules, 18(2), 2328-2375.

Khoo, H. E., Azlan, A., \& Ismail, A. (2015). Sauropus androgynus Leaves for Health Benefits: Hype and the Science. The Natural Products Journal, 5, 115-123.

Moharram, H. A. ., \& Youssef, M. M. (2014). Methods for Determining the Antioxidant Activity: A Review. Alexandria Journal of Food Science and Technology, 11(1), 31-42.

Nijveldt, R. J., Van Nood, E., Van Hoorn, D. E. C., Boelens, P. G., Van Norren, K., \& Van Leeuwen, P. A. M. (2001). Flavonoids: A review of probable mechanisms of action and potential 
DOI : https://doi.org/10.24843/JFU.2021.v10.i01.p01

pISSN: 2301-7716; eISSN: 2622-4607

Jurnal Farmasi Udayana, Vol 10, No 1, Tahun 2021, 01-12

applications. The American Journal of Clinical Nutrition, 74, 418-425.

Pandey, A., \& Tripathi, S. (2014). Concept of standardization, extraction and pre phytochemical screening strategies for herbal drug. Journal of Pharmacognosy and Phytochemistry, 2(5), 115-119.

Patonah, Susilawati, E., \& Riduan, A. (2017). Aktivitas Antiobesitas Ekstrak Daun Katuk (Sauropus androgynus L. Merr) Pada Model Mencit Obesitas. Pharmacy, 14(02), 137-152.

Petrus, A. J. A. (2013). Sauropus androgynus (L.) Merrill - a potentially nutritive functional leafyvegetable. Asian Journal of Chemistry, 25(17), 9425-9433.

Quideau, S., Deffieux, D., Douat-casassus, C., \& Pouysøgu, L. (2011). Natural Products Plant Polyphenols : Chemical Properties, Biological Activities, and Synthesis **. Angew. Chem. Int., 50, 586-621.

Rusdi, N. K., Hikmawanti, N. P. E., Maifitrianti., Ulfah, Y. S., \& Annisa, A. T. (2018). Aktivitas Afrodisiaka Fraksi dari Ekstrak Etanol 70\% Daun Katuk (Sauropus androgynus (L.) Merr) Pada Tikus Putih Jantan. Pharmaceutical Sciences and Research (PSR), 5(3), 123-132.

Singh, S., \& Singh, R. P. (2008). In vitro methods of assay of antioxidants: An overview. Food Reviews International, 24(4), 392-415.

Stalikas, C. D. (2007). Extraction, separation, and detection methods for phenolic acids and flavonoids. J. Sep. Sci., 30, 3268-3295.

Wan, C., Yu, Y., Zhou, S., Liu, W., Tian, S., \& Cao, S. (2011). Antioxidant activity and free radical-scavenging capacity of Gynura divaricata leaf extracts at different temperatures. Pharmacognosy Magazine, 7(25),
40-45.

Watson, R. R. (Ed.). (2019). Polyphenols in Plants: Isolation, Purification and Extract Preparation (2nd ed.). London: Academic Press Elsevier.

Wijono, S. H. (2004). Isolasi dan Identifikasi Asam Fenolat pada Daun Katu (Sauropus androgynus (L.) Merr). Makara, Kesehatan, 8(1), 3236.

World Health Organization. (1998). Quality control methods for medicinal plant materials. Geneva, Switzerland: World Health Organization.

Yang, J., Paulino, R., Janke-Stedronsky, S., \& Abawi, F. (2007). Free-radicalscavenging activity and total phenols of noni (Morinda citrifolia L.) juice and powder in processing and storage. Food Chemistry, 102(1), 302-308. 